\title{
The Impact of Socio-Economic and Gender Factors on Common Mental Disorders Among Married Women
}

\author{
Fetia Nursih Widiastuti ${ }^{1}$, Dwini Handayani ${ }^{2}$ \\ Magister Program in Population and Labour Studies, Faculty of Economics and Business, \\ Universitas Indonesia, Depok, Indonesia ${ }^{1}$ \\ Faculty of Economics and Business, Universitas Indonesia, Depok, Indonesia ${ }^{2}$ \\ \{fetianursih@gmail.com ${ }^{1}$, dwiniarianto@yahoo.com $\left.{ }^{2}\right\}$
}

\begin{abstract}
This study aims to determine the impact of socio-economic and gender factors on common mental disorders in married women in Indonesia. Using the National Women's Life Experience Survey in 2016 and binary logistic regression, the common mental disorders were measured based on detailed questions consisting of 20 Self Reporting Questionnaire (SRQ-20) questions with $5 / 6$ cut off. The results of the inferential analysis show that socio-economic factors and gender factors significantly influence emotional, mental disorders. The socio-economic factors that significantly influence common mental disorders are the level of education and wealth index. Gender factors that significantly influence the common mental disorders of married women are the duration of the marriage, husbands' activities and domestic violence by husbands.
\end{abstract}

Keywords: Common Mental Disorders, Srq-20, Binary Logistic Regression.

\section{Introduction}

According to the Global Burden of Disease, depression is thought to be the second important disease burden ranked by 2020 [1]. A total of 322 million people in the world (4.4\%) were depressed, and 264 million people (3.6\%) had anxiety disorders with a higher percentage of women than men [2]. Cases of depression and anxiety disorders are most prevalent in Southeast Asia. According to Riskesdas 2007 and 2013 results, the prevalence of women to experience common mental disorders is higher than that of men with a decrease in 2013. Women experience depression twice as much as men [1], [3]. The unique condition of women with their natures as pregnant and childbearing women and their role in family and society causes women to be more vulnerable to poor mental health conditions [4].

Mental health is generally affected by social, economic, and physical and environmental conditions [5], [6]. Mental health needs to be improved because it will impact on physical health and general health. Also, mental health has an impact on the labor market and human resources [7] - economic costs for mental disorders related to human capital, namely direct costs and indirect costs. Direct costs include medication, whereas indirect costs are income losses due to disability, death, non-employment or early retirement [8]. Women's mental health can be understood through several factors, namely his biological, social, cultural, 
economic and personal conditions. In addition, the environment also affects women's mental health.

One way of measuring common mental disorder is Self Reporting Questionnaire-20/SRQ20 [9]. SRQ-20 is an easy, inexpensive, and effective way to measure common mental disorders. It is said to be cheap because it costs a little, takes a fast time and does not require special human resources to provide an assessment [10]. SRQ-20 is widely used in developing countries, low education level, and low socioeconomic level $[9,10]$.

The SRQ-20 consists of 20 questions that contain a "yes" answer with a score of 1 and a "no" with a score of 0 . SRQ-20 can be done by filling out the questionnaire by yourself or by interview. The item points on SRQ-20 contain symptoms that lead to neurosis, symptoms of depression, symptoms of anxiety, somatic symptoms, cognitive symptoms, symptoms of energy decline. Educational variables, employment status and standard living index (Standart Living Index) as a socioeconomic indicator for common mental disorders of married women in India. These socio-economic factors directly or indirectly affect common mental disorders. Some empirical studies have found that low levels of education affect increasing common mental disorders [11], [12], [13]. People who do not work are more at risk of common mental disorders than people who work [11], [13], [14]. The level of wealth can estimate a person's financial stability [15]. The level of wealth using housing conditions and asset ownership affects mental health and psychological well-being [14], [15].

Gender and marital factors are factors related to married women and their husbands. Among the factors of gender and marriage is the duration of the marriage, husband's activity or husband's employment status [12], Domestic Violence experience my husband [12], and age at the first marriage [12], [16]. The longer married the more depressed the level of depression does not differentiate between men and women. This is influenced by the social and emotional impulses between couples, then by marriage, the condition of financial stability will increase and increase the protective attitude on both sides [17]. A husband who does not work or loses a job will decrease income in the family. This condition leads to a decline in mental health and psychological well-being for couples and children [7]. Unemployed and jobless husbands are also prone to decrease mental health. Research in Australia also mentions that a woman can decrease her mental health level if her husband loses a job, but the husband does not experience a decline in mental health if his wife loses his job [18]. Women who experience violence tend to have general mental health problems such as depression, anxiety, post-traumatic stress, sleep disturbances, alcohol use disorders, somatic and psychological complaints [19], [20].

\section{Method}

This study uses secondary data derived from data collection of the National Women's Life Survey (SPHPN) in 2016. SPHPN 2016 is a survey that explores information about violence experienced by women. This survey is a collaboration between the Central Bureau of Statistics (BPS) with the Ministry of Women Empowerment and Child Protection. The purpose of SPHPN 2016 is to provide basic data and indicators related to women's life experience. The unit of analysis in this study were women who married once aged 15-64 years. Once the marriage has chosen because some independent variables, the question is to the last husband. So, the information focus if women marriage once. While, one-time marriage was chosen because age at the first marriage question was not included in the survey questionnaire, so it was approached with the endorsement of the last marriage. The endorsement of the last marriage minus the year of birth will be an age at the first marriage for married women once. 
The dependent variable in this study is the common mental disorder of married women. Female emotional disturbance is derived from Self Reporting Questionnaire-20 (SRQ-20). SRQ-20 consists of 20 questions that must be answered with "yes" or "no." The total score of SRQ-20 is 20. The "yes" answer is scored one which means the symptoms are experienced during the past month. While the answer is "no" given a score of zero which means there are no symptoms during the last month. Based on the results of Riskesdas 2007 and 2013 publications, as well as previous studies on SRQ-20, the cut-off point in SRQ-20 is six. So women are said to have a common mental disorder if the total score of SRQ-20 is six or more.

The independent variables in this study are socio-economic factors and gender factors. Socio-economic factors include education, employment status and wealth index. While gender factors include the duration of the marriage, husband activities, experience of domestic violence and age at the first marriage, other independent variables are self-rated health, a number of children ever born, as well as residential areas. Domestic violence in this study consisted of physical violence, emotional violence, and sexual violence. It is said to experience domestic violence if of all the above questions there is at least one answer [21], [22], [23].

In this study, the method used is descriptive and inferential analysis. Descriptive analysis is used to describe the common mental disorders general condition of married women in Indonesia based on individual characteristics such as education, employment status and wealth index, marriage duration, husband activity, domestic violence, first age marriage, self-rated health, number of children born living, and living area. The inferential analysis used in this research is binary logistic regression analysis.

\section{Result and discussion}

Based on each item in each symptom, a person can be said to experience a symptom if at least one of the questions on the symptoms is answered yes. The percentage of the five symptoms is shown in Figure 1.

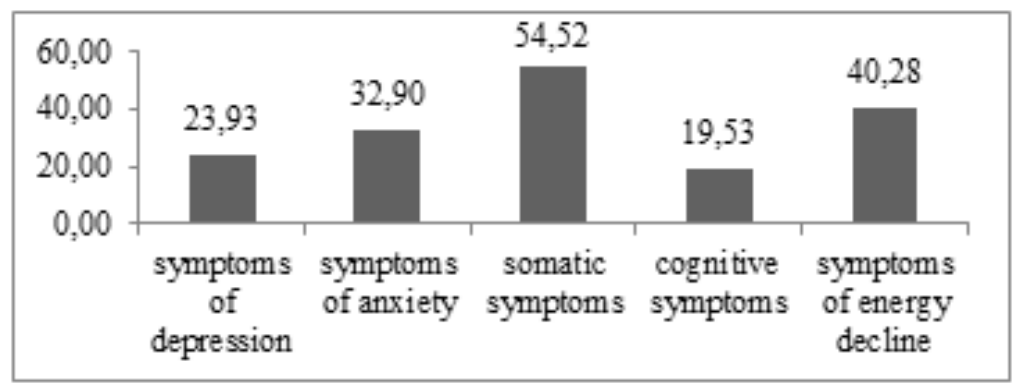

Fig. 1. The Symptoms of Common Mental Disorder Among Married Women

In model 1 below it can be seen that the socio-economic factors, namely the level of education, employment status and wealth index have a significant effect on the common mental disorder condition of married women. While on model 2, gender and marriage factors, there are two variables that have no significant effect on the duration of marriage and age at the first marriage. In model 3 which is the last model, it is known that the variable of education level, wealth index, marriage duration, husband activity, husband alcohol 
consumption, domestic violence, health status, and a number of children ever born have a significant effect on the common mental condition of the married woman.

The level of education has a statistically significant effect on the common mental disorder condition of married women. People with low education have limitations in coping patterns to the problems experienced [13]. While people with higher education have the ability and knowledge more to overcome the problems of life and tend to be able to overcome the problems, women with a high education will delay marriage, resulting in low fertility rates and fewer children and better mental health [4].

Table 1. Binary Logistic Regression Result of Independent Variable on Common Mental Disorder Among Married Women

\begin{tabular}{|c|c|c|c|c|c|c|}
\hline \multirow{2}{*}{ Independent Variable } & \multicolumn{2}{|c|}{ Model 1} & \multicolumn{2}{|c|}{ Model 2} & \multicolumn{2}{|c|}{ Model 3} \\
\hline & Koef B & $\operatorname{Exp}(\mathrm{B})$ & Koef B & $\operatorname{Exp}(\mathrm{B})$ & Koef B & $\operatorname{Exp}(\mathrm{B})$ \\
\hline (1) & (2) & (4) & (2) & $(4)$ & $(2)$ & (4) \\
\hline constanta & $-2,173$ & $0,114^{* * *}$ & $-2,078$ & $0,125 * * *$ & $-2,737$ & $0,065 * * *$ \\
\hline $\begin{array}{l}\text { Education } \\
\text { Elementary School and lower } \\
\text { Junior High School } \\
\text { Senior High School or more } \\
\text { (ref) }\end{array}$ & $\begin{array}{l}0,316 \\
0,235\end{array}$ & $\begin{array}{l}1,371^{* * *} \\
1,265^{* * *}\end{array}$ & & & $\begin{array}{l}0,390 \\
0,287\end{array}$ & $\begin{array}{r}1,478 * * * \\
1,332 * *\end{array}$ \\
\hline $\begin{array}{l}\text { Employment Status } \\
\text { Not Working } \\
\text { Working (ref) } \\
\text { Wealth Index }\end{array}$ & 0,125 & $1,133 *$ & & & 0,078 & 1,081 \\
\hline Low & 0,597 & $1,817 * * *$ & & & 0,493 & $1,636^{* * *}$ \\
\hline $\begin{array}{l}\text { Medium } \\
\text { High (ref) }\end{array}$ & 0,311 & $1,365 * * *$ & & & 0,294 & $1,341 * *$ \\
\hline $\begin{array}{l}\text { Marriage Duration } \\
\text { Husband Activity }\end{array}$ & & & 0,002 & 1,002 & $-0,013$ & $0,987^{* * *}$ \\
\hline $\begin{array}{l}\text { Others } \\
\text { Working (ref) }\end{array}$ & & & 0,443 & $1,557 * * *$ & 0,452 & $1,572 * * *$ \\
\hline $\begin{array}{l}\text { Household Violence } \\
\text { Yes } \\
\text { No (ref) }\end{array}$ & & & 1,306 & $3,691 * * *$ & 1,274 & $3,573 * * *$ \\
\hline $\begin{array}{l}\text { Age at The First Marriage } \\
<18 \text { years } \\
\geq 18 \text { years (ref) }\end{array}$ & & & 0,001 & 1,001 & $-0,162$ & 0,851 \\
\hline $\begin{array}{l}\text { Self Rate Health } \\
\text { Bad } \\
\text { Good (ref) }\end{array}$ & & & & & 1,459 & $4,301 * * *$ \\
\hline $\begin{array}{l}\text { Number of Children Ever } \\
\text { Born } \\
6 \text { or more } \\
3-5 \\
0-2 \text { (ref) }\end{array}$ & & & & & $\begin{array}{l}0,379 \\
0,248\end{array}$ & $\begin{array}{l}1,461 * * \\
1,282 * * *\end{array}$ \\
\hline $\begin{array}{l}\text { Living Area } \\
\text { Urban } \\
\text { Rural (ref) }\end{array}$ & & & & & $-0,034$ & 0,967 \\
\hline
\end{tabular}


The status of household welfare is proxied through a wealth index based on housing conditions and ownership of household assets. The degree to which a person's financial stability can be estimated with his level of wealth [15]. Prosperous people are economically not too vulnerable to mental disorders. Poverty is strongly associated with common mental disorder. Women living in poverty, unemployed or have low wages, and low education are powerful things that affect mental disorders [1].

The duration of marriage has a statistically significant effect on the common mental condition of women. The results of the analysis show that the addition of a marriage duration of one year will reduce the tendency of women to experience common mental disorders. The longer the marriage, the social and common impulses between couples get stronger, then the financial stability in the family increases, thus reducing the level of common mental disorders of the wife [17].

Husband activity is a statistically significant effect on the mental condition of a married woman with a level of significance one percent. Other activities, in this case, are looking for work/unemployment, pensions, students/students, and long-term paralysis/illness. Husband as head of the family has the main task in earning a living. However, when the condition of the husband is not supportive, for example, unemployed husbands, retirees, or husbands paralyzed / sick long term, the burden is transferred to the wife. The mental health of the wife becomes impaired when her husband is unemployed or loses his job [7], [18].

The results of binary logistic regression analysis show that domestic violence statistically affects the common mental disorder condition of married women with a level of significance of one percent. Yoshihima et al. (2009) mention that common violence is an important factor in the linkage of domestic violence to mental disorders in addition to physical violence and sexual violence. Women who experience violence by husbands create trauma in addition to the physical pain they experience. Women who have experienced physical or sexual abuse tend to think of ending their lives [24].

Self-rated health statistically significant affects the common mental disorder condition of married women with a level of significance of one percent. This condition is by the results of the study of [25]. Assessment of personal health tends to be subjective. Women who feel less healthy, actually not necessarily physically sick, but more to somatic symptoms experienced, wherein this study, somatic symptoms is a symptom of common mental disorders with the largest percentage.

\section{Conclusion}

The results of the inferential analysis show that socio-economic factors and gender and marital factors significantly influence common mental disorders. The socio-economic factors that significantly influence common mental disorders are the level of education and wealth index. While the status of work does not significantly influence the common mental disorders of married women. Gender and marital factors that significantly influence the common mental disorders of married women are the duration of the marriage, husbands' activities and domestic violence by husbands. While the first marriage age is not a statistically significant effect on common mental disorders. In addition, it was found that self-rated health and live birth children had a significant effect on the occurrence of common mental disorders, while residential areas did not have a significant effect. The same results are also found in common mental disorder symptoms. However, the live birth child does not significantly affect all the symptoms of common mental disorders. 
Acknowledgments. This article's publication is supported by PITTA grant from Universitas Indonesia.

\section{References}

[1] World Health Organization and Mental Health Determinants and Populations Team, Women's mental health: an evidence-based review. Geneva: World Health Organization, 2000.

[2] World Health Organization, Depression and other common mental disorders: global health estimates. Geneva, 2017.

[3] C. Kuehner, "Why is depression more common among women than among men?," The Lancet Psychiatry, vol. 4, no. 2, pp. 146-158, 2016.

[4] D. E. Stewart, "Social determinants of women's mental health," J. Psychosom. Res., vol. 63, no. 3, pp. 223-224, Sep. 2007.

[5] J. Allen, R. Balfour, R. Bell, and M. Marmot, "Social determinants of mental health," Int. Rev. Psychiatry, vol. 26, no. 4, pp. 392-407, Aug. 2014.

[6] S. Mendolia, "The impact of husband's job loss on partners' mental health," Rev. Econ. Househ., vol. 12, no. 2, pp. 277-294, Jun. 2014.

[7] S. Trautmann and H. Wittchen, "Do our societies react appropriately to the burden of mental disorders ?," Science \& Society, EMBO reports, vol. 17, no. 9, pp. 1245-1249, 2016.

[8] M. Beusenberg and J. Orley, A user's guide to the Self Reporting Questionnaire (SRQ). Geneva: World Health Organization, 1994.

[9] T. Harpham et al., "Measuring mental health in a cost-effective manner," Health Policy Plan., vol. 18, no. 3, pp. 344-349, 2003.

[10] S. Idaiani and A. Y. Kristanto, "Analisis Gejala Gangguan Mental Emosional Penduduk Indonesia," Maj. Kedokt. Indones., vol. 59, no. 10, pp. 473-479, 2009.

[11] R. Shidhaye and V. Patel, "Association of socio-economic, gender and health factors with common mental disorders in women: a population-based study of 5703 married rural women in India," Int. J. Epidemiol., vol. 39, no. 6, pp. 1510-1521, Dec. 2010.

[12] G. Widakdo and Besral, "Efek Penyakit Kronis terhadap Gangguan Mental Emosional," Kesehat. Masy. Nas., vol. 7, no. 7, pp. 309-316, 2013.

[13] N. A. John, J. Edmeades, and L. Murithi, "Child Marriage and Psychological Wellbeing in Niger and Ethiopia," IUSSP Conf. Cape Town, South Africa, pp. 2-7, 2017.

[14] K. N. Carter, T. Blakely, S. Collings, F. I. Gunasekara, and K. Richardson, "What is the association between wealth and mental health?," J. Epidemiol. Community Heal., vol. 63, no. 3, pp. 221-226, Mar. 2009.

[15] Y. Abraham, N. Yigzaw, and F. Zewde, "Factors Associated with Common Mental Disorders among Women of Reproductive Age Group at Arbaminch Town, Southern Ethiopia: Cross Sectional Study," J. Psychiatry, vol. 21, no. 2, pp. 1-6, 2018.

[16] S. J. Gibb, D. M. Fergusson, and L. J. Horwood, "Relationship duration and mental health outcomes: findings from a 30-year longitudinal study," Br. J. Psychiatry, vol. 198, no. 1, pp. 24-30, Jan. 2011.

[17] M. Bubonya, D. A. Cobb-Clark, and M. Wooden, "Job loss and the mental health of spouses and adolescent children," IZA J. Labor Econ., vol. 6, no. 1, p. 6, Dec. 2017.

[18] M. K. Gomel, A Focus on Women. Geneva: World Health Organization, 2010.

[19] G. Ferrari et al., "Domestic violence and mental health: a cross-sectional survey of women seeking help from domestic violence support services," Glob. Health Action, 
vol. 7 , no. 1, p. 25519 , Dec. 2014.

[20] M. Nasrullah, R. Zakar, and M. Z. Zakar, "Child marriage and its associations with controlling behaviors and spousal violence against adolescent and young women in Pakistan," J. Adolesc. Heal., vol. 55, no. 6, pp. 804-809, 2014.

[21] A. Raj, "When the mother is a child: the impact of child marriage on the health and human rights of girls," Arch. Dis. Child., vol. 95, no. 11, pp. 931-935, Nov. 2010.

[22] S. Abdullah, H. Qureshi, and S. Quayes, "The adverse effect of child marriage on women's economic well being in Bangladesh - can microfinance help?," J. Dev. Areas, vol. 49, no. 4, pp. 109-125, 2015.

[23] K. Devries et al., "Violence against women is strongly associated with suicide attempts: Evidence from the WHO multi-country study on women's health and domestic violence against women," Soc. Sci. Med., vol. 73, no. 1, pp. 79-86, Jul. 2011

[24] L. Mewton and G. Andrews, "Poor self-rated health and its associations with somatisation in two Australian national surveys," BMJ Open, vol. 3, no. 6, p. e002965, Jun. 2013. 